\title{
National Satellite Land Remote Sensing Data Archive
}

\section{Background}

The National Satellite Land Remote Sensing Data Archive (NSLRSDA) resides at the U.S. Geological Survey's (USGS) Earth Resources Observation and Science (EROS) Center. Through the Land Remote Sensing Policy Act of 1992 (refer to http://thomas.loc.gov/cgi-bin/query/ $z$ ?c102:H.R.6133.ENR:), the U.S. Congress directed the Department of the Interior (DOI) to establish a permanent Government archive containing satellite remote sensing data of the Earth's land surface and to make the data easily accessible and readily available. This unique DOI/ USGS archive provides a comprehensive, permanent, and impartial observational record of the planet's land surface obtained throughout more than five decades of satellite remote sensing.

Satellite-derived data and information products are primary sources used to detect and understand changes
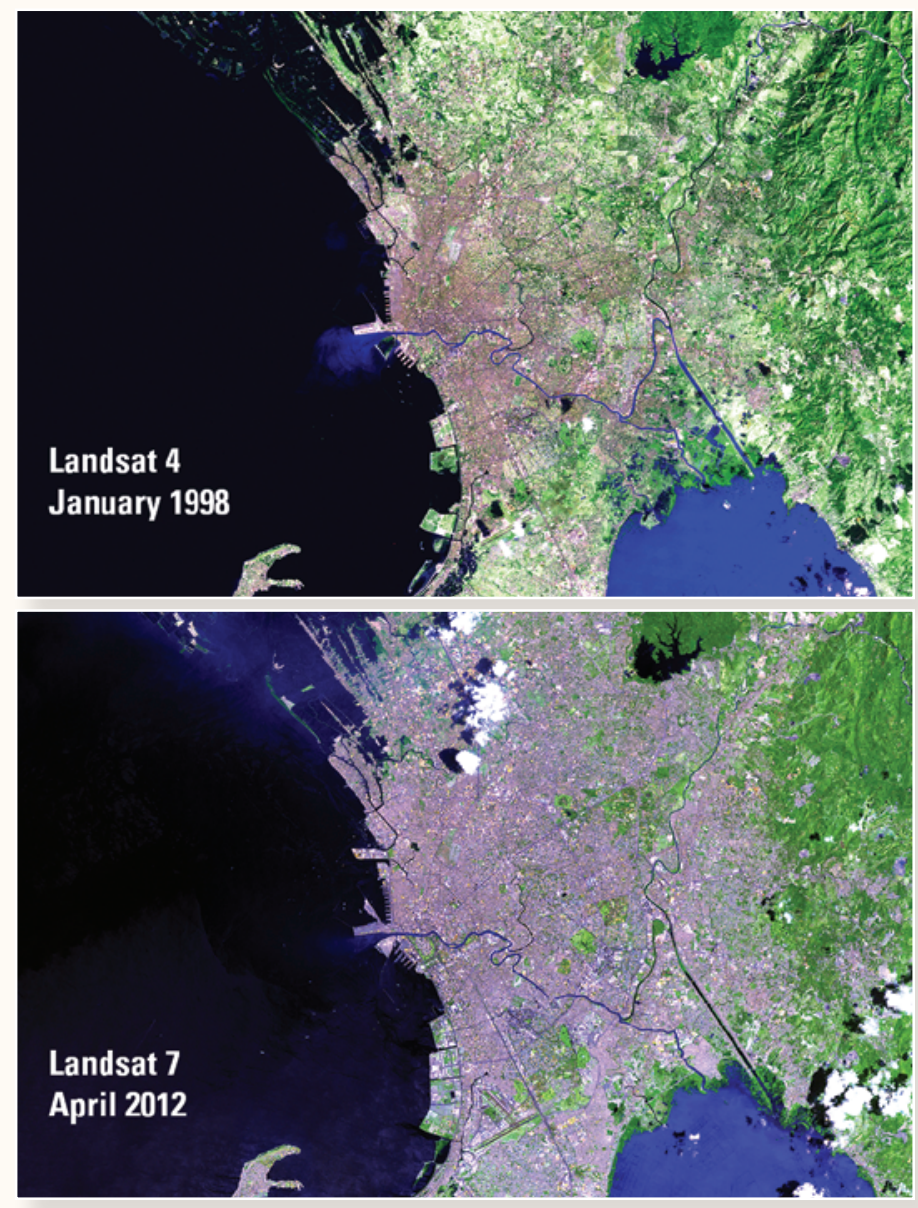

These satellite images reveal urban expansion in and around the Philippine capital of Manila. such as deforestation, desertification, agricultural crop vigor, water quality, invasive plant species, and certain natural hazards such as flood extent and wildfire scars. Comparisons of satellite images through time are a powerful tool for studying these phenomena.

Beyond the usefulness of determining land use or land cover change on a global scale, the NSLRSDA holdings enable scientists to study landscape variations, at local or regional scales, identify potential energy and mineral resource areas, help assess environmental quality degradation, and contribute to responsible development of our Nation's natural resources.
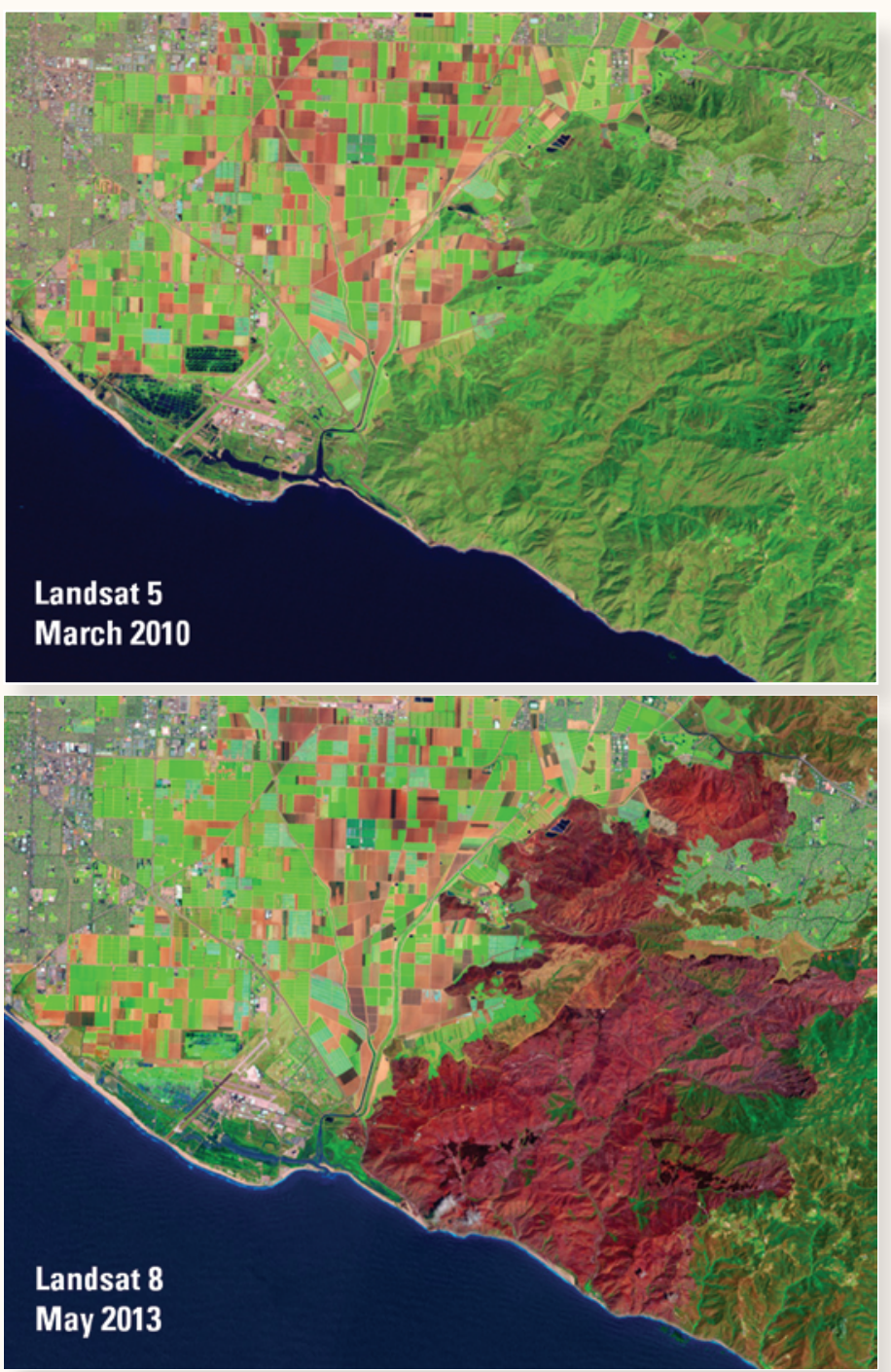

These before-and-after Landsat images reveal the scorched footprint of the May 2013 Camarillo Springs Fire in southern California. 


\section{Contents}

NSLRSDA contains film and digital records from the 1960s to the present day. Table 1 highlights some of the collections in the archive:

NSLRSDA collections provide unique observations of our Nation or the globe from different periods of time, through various cameras or sensors, and at ground resolutions ranging from less than 1 to 1,000 meters.

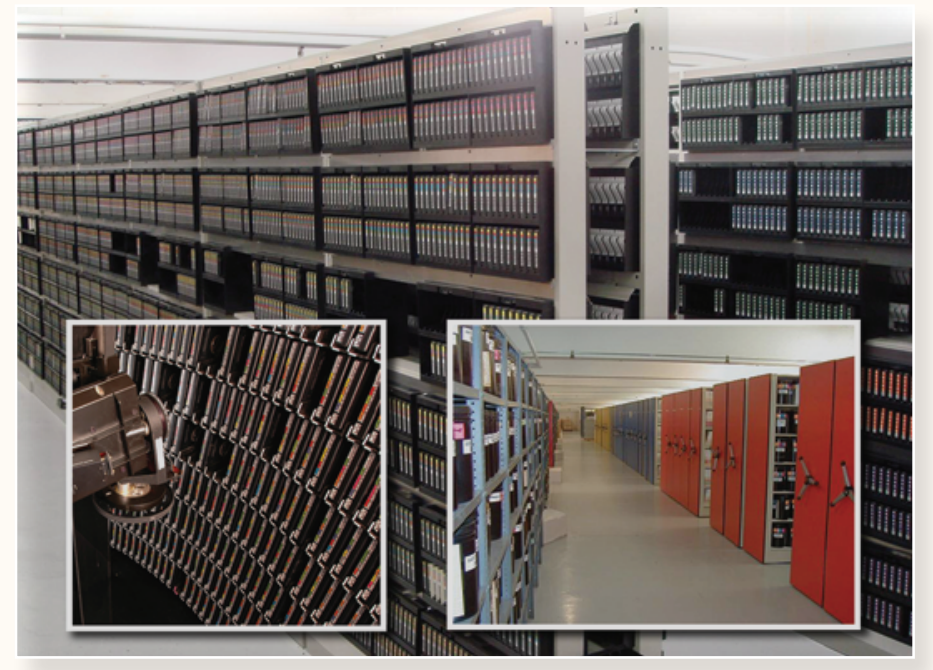

The archives at EROS holds millions of aerial photographs and satellite images. These data are stored on film and electronic media and preserved in environmental controlled archive space.
Table 1. The National Satellite Land Remote Sensing Data Archive (NSLRSDA) collection details.

\begin{tabular}{|c|c|c|}
\hline Collection name & Time span & $\begin{array}{l}\text { Ground } \\
\text { resolution }\end{array}$ \\
\hline Declassification I & $1960-1972$ & $2-153$ meters \\
\hline Declassification II & 1963-1980 & $0.6-10$ meters \\
\hline Large Format Camera & 1984 & $10-15$ meters \\
\hline Landsat Multispectral Scanner & 1972-1992 & 80 meters \\
\hline Landsat Thematic Mapper & 1982-2012 & 30 meters \\
\hline $\begin{array}{l}\text { Landsat Enhanced Thematic } \\
\text { Mapper Plus }\end{array}$ & $\begin{array}{l}\text { 1999-still } \\
\text { operating }\end{array}$ & $\begin{array}{l}15 \text { or } 30 \\
\text { meters }\end{array}$ \\
\hline $\begin{array}{l}\text { Landsat Operational Land } \\
\text { Imager }\end{array}$ & $\begin{array}{l}\text { 2013-still } \\
\text { operating }\end{array}$ & $\begin{array}{l}15 \text { or } 30 \\
\text { meters }\end{array}$ \\
\hline Landsat Thermal Infrared Sensor & $\begin{array}{l}\text { 2013-Still } \\
\text { operating }\end{array}$ & 100 meters \\
\hline Landsat Orthoimagery & $1972-2003$ & $15-80$ meters \\
\hline Global Land Surveys & $1972-2011$ & $15-80$ meters \\
\hline $\begin{array}{l}\text { Systeme Pour l'Observation de } \\
\text { la Terre }\end{array}$ & 1986-1998 & $\begin{array}{l}10 \text { or } 20 \\
\text { meters }\end{array}$ \\
\hline $\begin{array}{l}\text { Advanced Very High Resolution } \\
\text { Radiometer }\end{array}$ & $\begin{array}{l}\text { 1980-still } \\
\text { operating }\end{array}$ & 1,000 meters \\
\hline $\begin{array}{l}\text { Shuttle Radar Topography } \\
\text { Mission }\end{array}$ & 2002 & 30 meters \\
\hline GeoEye OrbView-3 & 2003-2007 & 1 or 4 meters \\
\hline
\end{tabular}

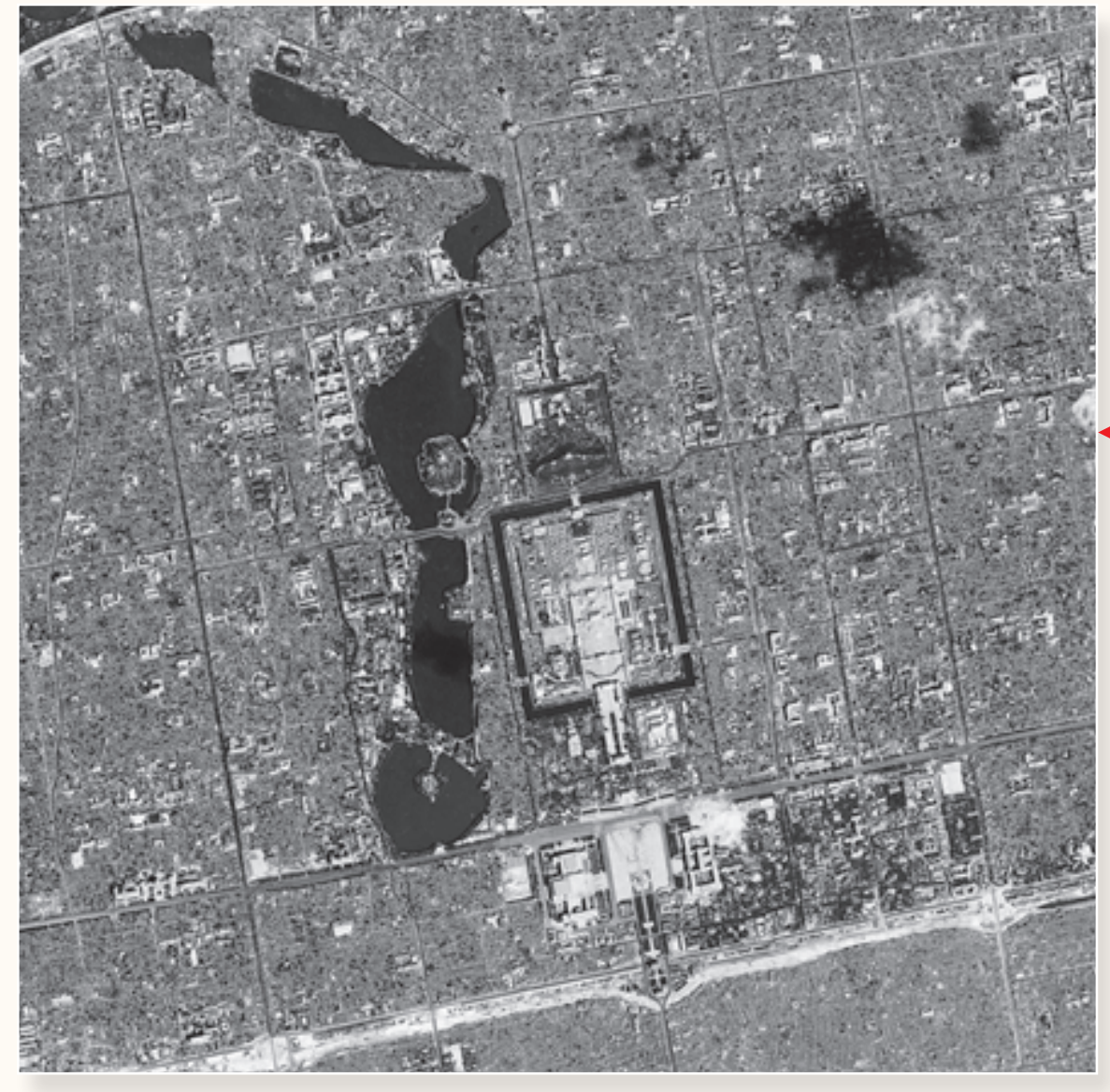

\section{How to Obtain the Data}

There are multiple ways to learn more about the NSLRSDA holdings and how to obtain the data. The primary NSLRSDA data access system, called Earth Explorer (http:// earthexplorer.usgs.gov), provides collection descriptions, a map-based query function, browse images, and means to download data at no charge.

This 1967 image showing Tiananmen Square in the city of Beijing, China, is part of a collection of declassified military intelligence satellite imagery. 